Agro-Science Journal of Tropical Agriculture, Food, Environment and Extension Volume 19 Number 3 (July 2020) pp. 32 - 39

ISSN 1119-7455

\title{
ATTRACTION OF Callosobruchus maculatus FABRICIUS (COLEOPTERA: CHRYSOMELIDAE: BRUCHINAE) TO PODS OF COWPEA PLANTS AT DIFFERENT DEVELOPMENTAL STAGES
}

\author{
${ }^{* 1,2}$ Ahuchaogu C.E. and ${ }^{3}$ Ojiako F.O. \\ ${ }^{1}$ Department of Animal \& Plant Science, University of Sheffield, S10 2TN, United Kingdom \\ ${ }^{2}$ Department of Crop Production and Protection, \\ Federal University Wukari, PMB 1020, Katsina-Ala Road, Wukari, Nigeria \\ ${ }^{3}$ Department of Crop Science, Federal University of Technology, PMB 1526 Owerri, Nigeria \\ *Corresponding author's email: ahuchaogu@fuwukari.edu.ng
}

\begin{abstract}
The cowpea beetle, Callosobruchus maculatus Fab. is an economically important pest of stored grain and causes serious damage to stored peas. The application of pesticides has been the generic control measure due to its effectiveness, affordability and ease of application. However, due to the apparent health and environmental consequences with pesticides, stakeholders are advocating for an alternative management approach that has less social and environmental impact and is more sustainable. Consequently, this study examined the attraction of mated female Callosobruchus maculatus to volatile blends collected from pods of cowpea plants (Borno-brown and black-eyed cultivars) at three developmental stages $\div$ developing podsie; 15-17 days after anthesis (daa), fully developed pods (18-20 daa) and mature pods ( $>20$ daa). The beetles' responses to the pods' odour were determined using a two-arm olfactometer, and gas chromatography-mass spectrometry (GC-MS) was used to identify and quantify the volatile compounds collected from the pods. The results showed that female $C$. maculatus attraction increased with the pod's age, and that the composition and abundance of volatile compounds varied between cowpea cultivars and the pod's developmental stage. These findings form an important bases towards developing alternative approach for the management of bruchids.
\end{abstract}

Key words: volatile compounds, cowpea plants, GC-MS, pod's developmental stage, days after anthesis

\section{INTRODUCTION}

The dry seeds of cowpea (Vigna unguiculata L. Walp) is an important food and cash crop to farmers (mainly, cowpea growers in tropical regions) and exporting nations. But its production is facing serious pest infestations, especially, from the cowpea bruchid, Callosobruchus. maculatus. The gravid females of this storage beetle lay eggs on pods of cowpea plant in the field (Taylor and Agbaje, 1974; Ouedraogo and Huignard, 1981; Djossou, 2006; Kebe and Sembene, 2011), and the egg-laden pods are harvested, kept in storage where cross infestations and re-infestations continue. Emerging adults leave a hole on the bean's surface and have mined out the internal tissue of the bean, thus damaging its economic value. As a result, farmers have to spray pesticides on their harvest to control the pest attack without understanding the consequences of their actions. The risks associated with pesticide usage have been well documented, and has triggered legislation banning its use, and the need for new, safer pest control methods.

Several studies have reported the attractiveness of plant volatile organic compounds (VOCs) to certain insect pests of agricultural importance
(Agelopoulos et al., 1999; Dudareva et al., 2004; Webster et al., 2008). For example, the cosmopolitan granary pest Acanthoscelides obtectus (Say), the pea weevil, Bruchus pisorum L. and the legume pod borer (Maruca vitrata Fab.) are attractedby the volatile compounds from dry bean cultivars (Khelfane-Goucem et al., 2014), Pisum sativum L. (Ceballos et al., 2015) and Vigna unguiculata (Bendera et al., 2015; Zhou et al., 2015), respectively. Also, the use of methyl eugenol and protein-bait from brewery waste on modified lynfield trap were effective in mass-trapping Bactrocera invadens D.T.W. (Ugwu et al., 2018). Most plant volatiles are sulphuric compounds, terpenoids, fatty acid derivatives and nitrogencontaining compounds (Pare and Tumlinson, 1999), and are mainly lipophilic products with molecular masses less than 300. The most extensively studied vegetative volatile is Isoprene (Sharkey and Yeh, 2001), a thermoregulatory which protects plants against heat-stress (Sharkey et al., 2008), whereas other substances are released to protect plants against natural enemies (Takabayashi and Dicke, 1996; Hammer et al., 2003) and attract pollinators (Reinhard et al., 2004). Studies have shown that the 
quantity and number of the volatile substances emitted are affected by low light conditions (Takabayashi et al., 1994) and high organic nitrogen fertilizers (Van Wassenhove et al., 1990). These volatile substances are released from different parts of a plant, and induce behavioural interactions between organisms. They are used by pest insects to identify, home-in on and utilise a preferred host type (Ignacimuthu et al., 2000; Uechi et al., 2007; Bruce et al., 2005; Webster et al., 2008).

Developing (Umar andTuraki, 2014; Zannou et al., 2003) and mature stages of cowpea plants (Caswell,1984) are susceptible to infestations by $C$. maculatus in the field. According to Messina (1984), female $C$. maculatus preferred fully developed pods to younger or mature pods, and were attracted to pods with exposed seeds compared to intact pods. In another study, a senesced banana leaf was preferred to other developmental stages (Abagale et al., 2019). These preferences have been suggested to be triggered by the volatile compounds emitted at the developmental stages. For example, the senesced banana leaf was found to contain $(2 \mathrm{R}, 5 \mathrm{~S})$-the aspirane as an active component unlike other developmental stages (Abagale et al., 2019) of the banana leaf. Also, soybean showed variances in the abundance and number of VOCs emitted at different developmental stages (Boué et al., 2003). These findings suggest there may be important chemical cues correlated with the host's life-history stage. There is therefore considerable evidence that the beetle interacts with the host plant long before the seeds are stored by farmers (Ouedraogo and Huignard, 1981; Taylor and Agbaje, 1974; Djossou, 2006; Kebe and Sembene, 2011).

Analysing the chemical components of cowpea pods at various developmental stages and the examination of the pest's behavioural attraction to such chemicals is important to predict how the life cycle of the plant influences its vulnerability to infestations by the pest. With this in mind, this chapter examines the response of cowpea beetle to volatiles from the pods of two cowpea varieties at different growth stages, and predicts that odour cues from pods' categories would induce attraction of $C$. maculatus. As a field-to-store pest, this measure is to identify the most vulnerable pod's growth stage to infestation together with the volatile compounds moulding such action.

\section{MATERIALS AND METHODS \\ Insect}

A wild strain of $C$. maculatus collected from infested Borno-brown beans in a farmer's field in Taraba State, Nigeria was used in this study. The strain was cultured in breeding containers $(17 \times 11.5 \mathrm{~cm})$, each having $200 \mathrm{~g}$ of uninfested whole Borno-brown bean. Lids of the containers were perforated to allow for ventilation. The cultures were kept in the lab. at a temperature of $28 \pm 2{ }^{\circ} \mathrm{C}$ and relative humidity of $30 \pm 5 \%$.

\section{Growing of Cowpea}

This was carried out in a greenhouse at Arthur Willis Environment Centre (AWEC), University of Sheffield, United Kingdom. The greenhouse day and night temperatures were maintained at $27 \pm 1^{\circ} \mathrm{C}$ and $22 \pm 1^{\circ} \mathrm{C}$, respectively. Relative humidity was $30-60 \%$ used throughout the study. The photoperiod was set at $9 \mathrm{~h}$ light and $15 \mathrm{~h}$ dark. Nine pots ( $30 \mathrm{~cm}$ diameter) each, were used for the study. Three clean seeds of Bornobrown and California black-eyed cultivars were sown per pot which was later thinned to a plant stand per pot after one week of germination. The plants were tagged at the onset of flowering (anthesis) to accurately estimate the pods' age (Plate 1).

The age classes were based on the number of days after onset of flowering as categorized below; 15-17 days after onset of flowering (developing pods) 18-20 days after onset of flowering (fully developed pods) 20 days after onset of flowering (mature pods).

Headspace Samples Collection from Cowpea Pods Headspace VOCs of the pods were trapped with air entrapment equipment from the cowpea plants at the defined developmental stages. All equipment was washed with detergent, rinsed with hexane and distilled water, and then dried in an oven at $120^{\circ} \mathrm{C}$ for $15 \mathrm{~h}$. Transparent oven bags used for the study were also pre-conditioned by heating them in an oven at $120^{\circ} \mathrm{C}$ for $15 \mathrm{~h}$. Each cowpea plant at various growth stage was enclosed with an oven bag, and charcoal-filtered air passed through a Porapak Q absorbent (Alltech Associates, Lancashire, UK) at a constant rate of $300 \mathrm{ml} / \mathrm{min}$ (Plate 2). All the connections were made with Polytetrafluoroethylene (PTFE) tubing and tape (Supelco, Bellefonte, PA). The VOCs absorbed on Porapak Q were eluted with $1 \mathrm{ml}$ of hexane. Extracted samples were further concentrated to $100 \mu \mathrm{l}$ by a low stream of nitrogen, and stored in glass vials in a freezer at $-80^{\circ} \mathrm{C}$.

Beetles' Response to Headspace Volatile Samples A two-arm olfactometer (Webster et al., 2008) was used to examine the attractiveness of $C$. maculatus to volatile samples collected from the plant pods. The olfactometer consists of three layers; the base (floor), the observation layer and the cover clipped together to form an eight-sided shape with a two-arm exposure chamber. Each layer is made of a transparent Perpex with $6 \mathrm{~mm}$ thickness. The first layer (floor) was lined with a What man filter paper base $(110 \mathrm{~mm})$ to provide traction for the weevil. Another layer, the observation arena had a hole ( $3 \mathrm{~mm}$ diam.) drilled from both edges into the two arms to accommodate the odour chambers. Then, a third layer (cover), all of the same size and shape had a hole (4 mm diam.) drilled at the centre. Two 60-ml BD plastiak's (syringes) served as the odour chambers. A Teflon tube $(1.5 \mathrm{~mm}$ ID $\times 3.2 \mathrm{~mm}$ OD) was used to connect each of the chambers to both arms of the olfactometer, and the connections were tightened with a PTFE tape. A $60-\mathrm{W}$ light bulb was positioned $1 \mathrm{~m}$ above the olfactometer to provide uniform illumination. 


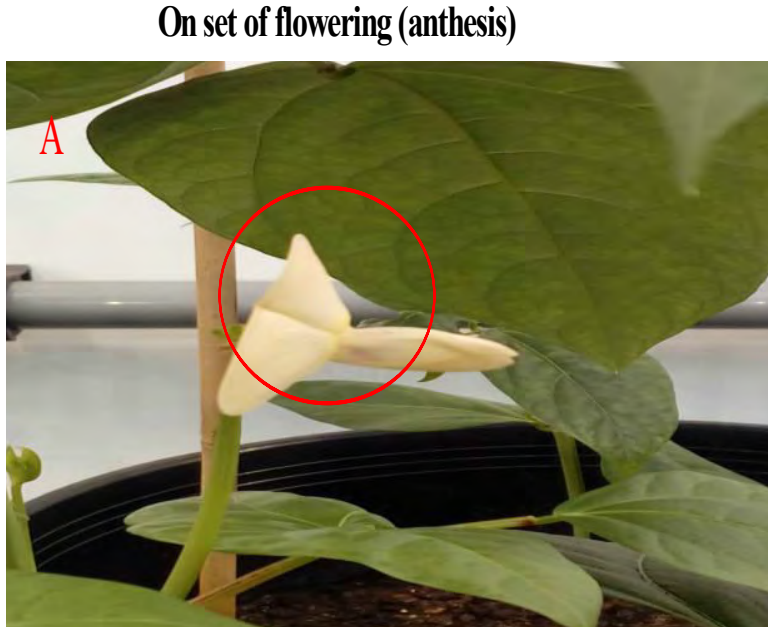

Fully developed pods: 14-19 daa

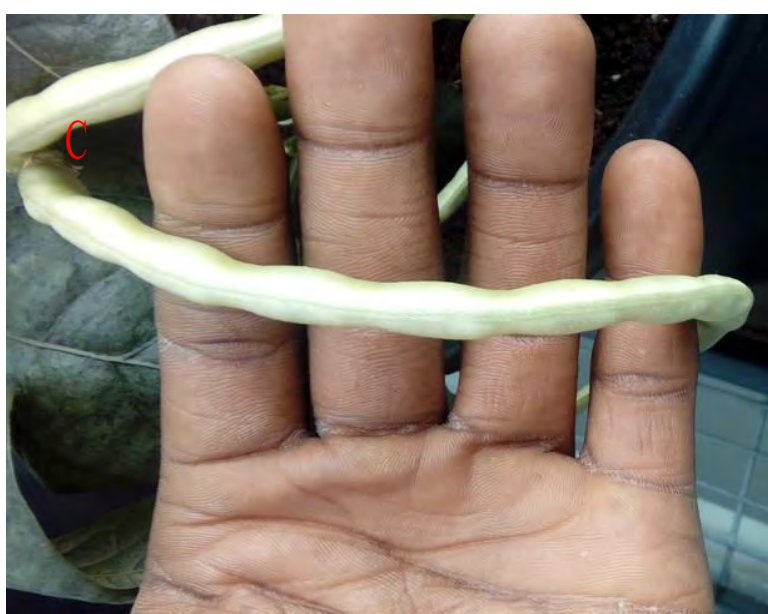

Plate 1: Onset of an thesis (A); developing pods: 0-12 daa (B); Fully developed pods: 14-19 daa (C); Mature pods: > 20 daa (D)

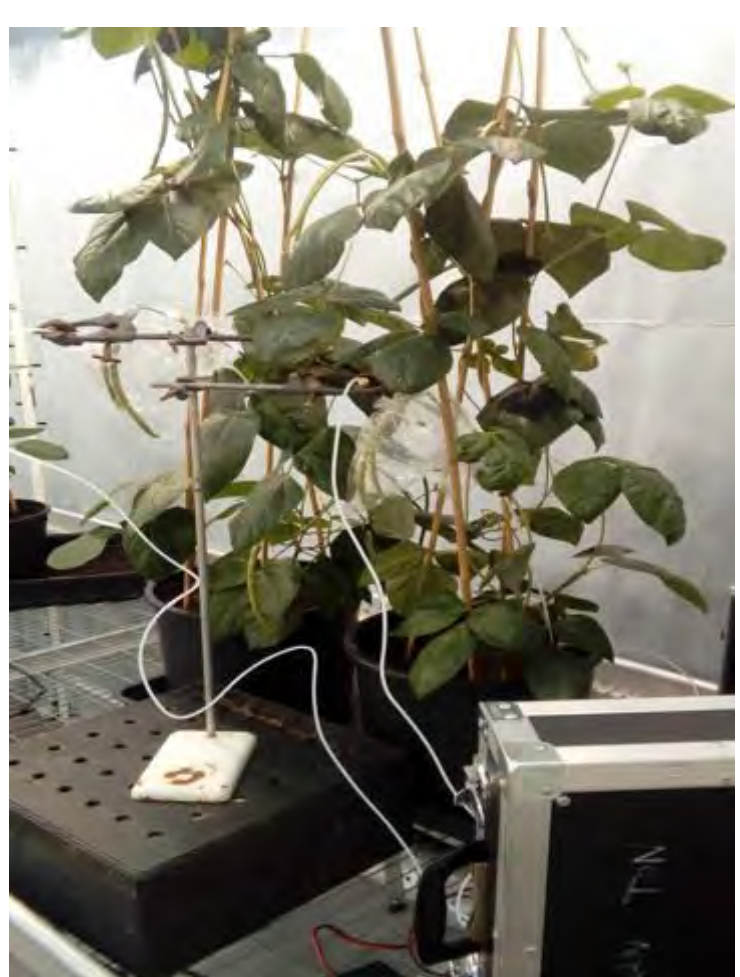

Plate 2: Collection of volatile organic compounds from cowpea pods

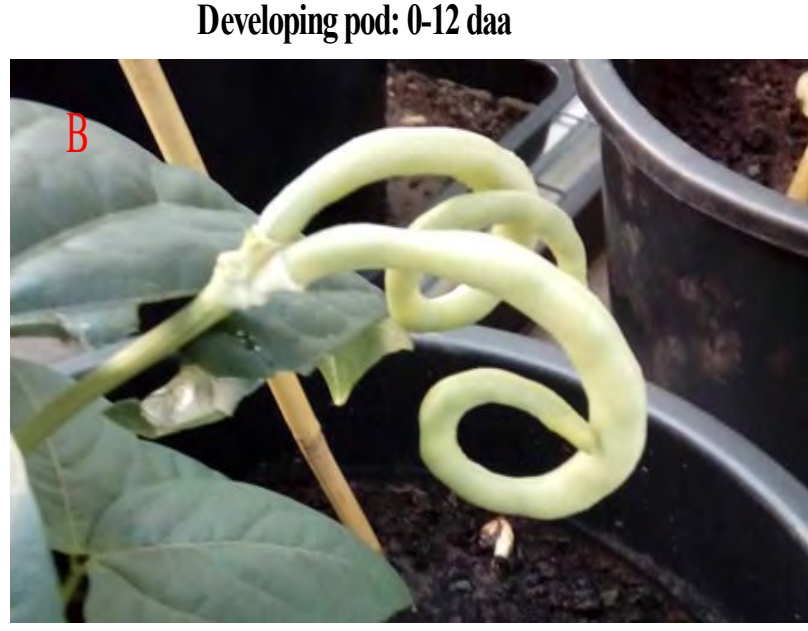

Mature pods: $>20$ daa

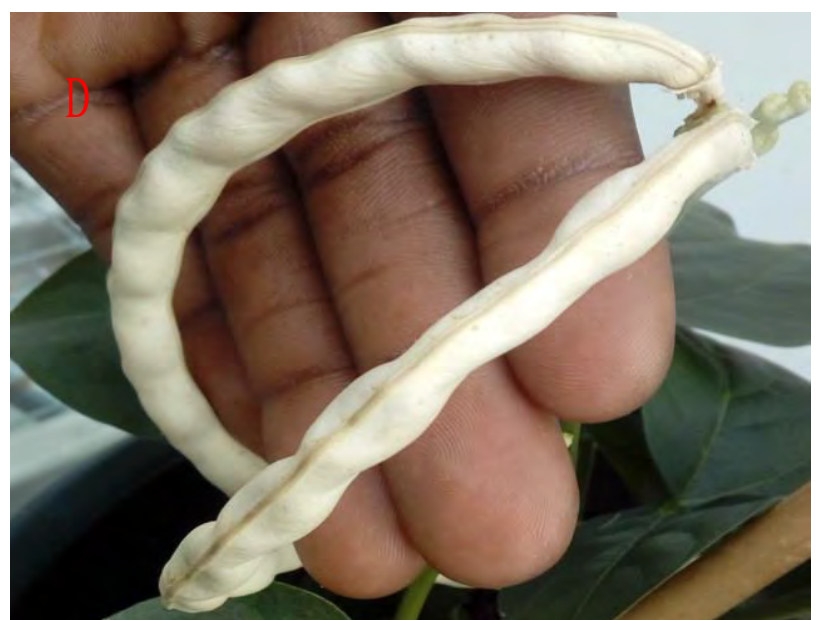

Twenty microliters $(20 \mu \mathrm{l})$ of volatiles samples from pods of the plants at the three different growth stages were applied on a piece of filter paper, and 1 min. was allowed for solvent evaporation. The treated filter paper was put into one of the odour chambers, while the second chamber was used as a control which contained a piece of filter paper treated with $20 \mu \mathrm{l}$ of hexane. A mated normal female of the beetle was then introduced into the centre of the olfactometer (observation arena). Air was drawn through both arms using a vacuum, and regulated with a flow meter at a rate of $100 \mathrm{ml} / \mathrm{min}$. After introduction, the beetle was given $3 \mathrm{~min}$. to settle in the observation arena, and the movement towards both arms was observed for $15 \mathrm{~min}$. Beetles that failed make any choice $5 \mathrm{~min}$. after introduction were regarded as "non-responders" and discarded. All materials used were washed, rinsed with distilled water, and then cleaned with $70 \%$ ethanol. Between 8-10 replicates were used.

\section{Coupled Gas Chromatography - Mass Spectrometry (GC - MS)}

The candidate compounds associated with the volatile samples from the plants' pods were identified using GC-MS. A $2 \mu \mathrm{L}$ of the air headspace sample was injected onto a capillary GC column $(30 \mathrm{~m} \times 0.25$ 
$\mathrm{mm}$ ID, $0.25 \mu \mathrm{m}$ film thickness), which is directly coupled to a mass spectrometer (PerkinElmer, Clarus $^{\circledR}$ SQ 8T). The carrier gas was helium with a flow rate of $1.02 \mathrm{ml} \mathrm{min}^{-1}$. Ionization was achieved by electron impact at $70 \mathrm{eV}, 230^{\circ} \mathrm{C}$. The injection port was maintained on a splitless mode. The GC initial oven temperature was maintained at $30^{\circ} \mathrm{C}$ $\min ^{-1}$, then ramped at $5^{\circ} \mathrm{C} \min ^{-1}$ to $240^{\circ} \mathrm{C}$, and held for $20 \mathrm{~min}$. Mass spectrum acquisition was scanned using a $\mathrm{m} / \mathrm{z}$ range from 35 to 450 . Candidate compounds were identified by comparing the chromatograph retention index and mass spectra with library database spectra using the National Institute of Standards and Technology (NIST) mass spectra search programme (version 2.2, NIST 14, Gaithersburg, Maryland, USA). The retention index of each compound identified was calculated using a series of straight alkanes $\left(\mathrm{C}_{8}-\mathrm{C}_{20}\right)$. The abundance of each identified compound was calculated by integrating the peak areas of the total ion chromatograph and averaged (Webster et al., 2008).

\section{Data Analysis}

The two-choice data on the beetles' responses to VOCs from each pod category were analysed using Chi-square $\left(\chi^{2}\right)$ test. Staked bars were used to present the proportion of time spent by the beetles in each arm of the olfactometer. To determine the similarities or differences among the compounds identified, the chemical analysis data on the abundance of volatile compounds from each pod category were subjected to permanova analysis and Tukey's HSD test was used for mean separation. The similarities of the compounds were interpreted using cluster analysis (Ward, 1963); whereas, principal component analysis (PCA) was used to indicate the ordination of the compounds and their relationships in the first two components. $\mathrm{R}$ statistical software (RStudio Version 1.1.456, 20092018) was used for all analyses.

\section{RESULTS}

Beetle Response to Headspace Volatile Compounds Olfactometer bioassays with natural samples of pod volatiles from Borno-brown beans showed that samples from developing pods $\left(\chi^{2}=0.051, \mathrm{df}=1, p\right.$ $=0.820)$ and fully developed pods $\left(\chi^{2}=0.170, \mathrm{df}=\right.$ $1, p=0.679)$ did not elicit responses from mated females of $C$. maculatus. However, there was significant attraction $\left(\chi^{2}=10.397, \mathrm{df}=1, p=0.001\right)$ to volatiles from mature pods (Figure 1). When the odour sources from pods of black-eyed beans was tested, the results showed that beetles spent significantly more time on arms with fully developed $\left(\chi^{2}=7.255, \mathrm{df}=1, p=0.007\right)$ and mature pods $\left(\chi^{2}=5.215\right.$, df $\left.=1, p=0.022\right)$ samples. But, when given a choice between volatiles from developing pods and the control, the female did not differentiate between the two treatments $\left(\chi^{2}=1.849\right.$, $\mathrm{df}=1, p=0.173)$ (Figure 1).

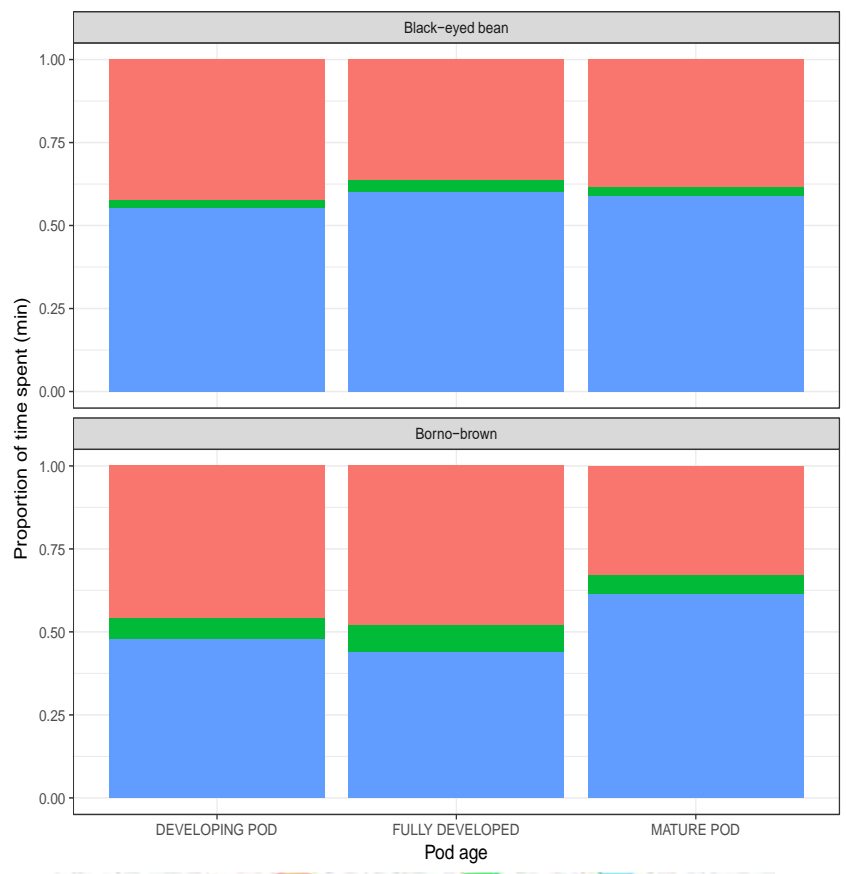

Beetle position $\square$ Control arm $\square$ Neutral $\square$ Volatile arm

Figure 1: Proportion of time spent by mated female $C$. aculatus in response to volatile stimuli from cowpea pods in a two-arm olfactometer

\section{Identification and Chemical Analysis of Volatile Compounds from Pods of Black-Eye Cowpea.}

The analysis revealed a total of 12 volatile compounds in the cultivar; eight were present on the developing and the fully developed pods, whereas, 11 compounds were detected on the mature pods (Table 1). Each of Hexanal and 3-Hexen-1-ol-acetate was only present on the mature and developing pods of black-eye cowpea, respectively. The PCA showed that components, 1 and 2 explained more than $99 \%$ of the variances in the abundance of VOCs examined on pods of black-eye cowpea (Figure 2), and the cluster analysis classified the compounds into three; benzaldehyde and ethanol, 2-(2-butoxyehoxy)acetate representing cluster 2 have similar abundance profile (Figure 3 ). The PCA biplot and dendrogram fully describe how the other compounds are related. The chemical analysis of the compounds indicated that they varied significantly among pods of blackeye cowpea $(\mathrm{F}=2351.6, \mathrm{df}=11,35, P<0.01$; Tables 1 and 2). Benzaldehyde, was significantly more abundant, followed by $\mathrm{p}$-xylene and $\mathrm{m}$-xylene on developing pods of black-eye cowpea; whereas, in the fully developed pods, benzaldehyde was more abundant, followed by m-xylene and p-xylene, although, they do not differ significantly (Table1). Similarly, ethanol, 2-(2-butoxyehoxy)-acetate, followed by $\mathrm{m}$-xylene and benzaldehyde were more abundant on mature pods of black-eye cowpea. However, 1-octane-3-ol was the least abundant compounds on developing pods of black-eye cowpea; whereas, Nonanal was the least abundant on the fully developed and mature pods of black-eye cowpea, respectively (Table 1). 
Table 1: GC-MS analysis of volatile organic compounds emitted by $2 \mu 1$ of air entrainment sample of black-eye cowpea pods (mean $\pm \mathrm{SD}$ )

\begin{tabular}{|c|c|c|c|}
\hline Developing pods & Fully developed pods & Mature pods RI & \\
\hline BENZALDEHYDE $16.790 \pm 0.241 \mathrm{a}$ & $17.839 \pm 0.329 \mathrm{a}$ & $18.818 \pm 0.071 \mathrm{a}$ & 962 \\
\hline P-XYLENE $18.684 \pm 0$ & $16.195 \pm 0.228 b$ & $17.267 \pm 0.191 \mathrm{a}$ & 865 \\
\hline M-XYLENE $19.029 \pm 0.242 \mathrm{a}$ & $15.072 \pm 0.103 \mathrm{c}$ & $17.633 \pm 0.095 \mathrm{a}$ & 866 \\
\hline LIMONENE $\quad 15.582 \pm 0.682 \mathrm{~cd}$ & $14.203 \pm 0.249 \mathrm{~d}$ & $15.592 \pm 0.011 \mathrm{~b}$ & 1030 \\
\hline NONANAL13.376 $\pm 0.391 \mathrm{f}$ & $13.375 \pm 0.065 \mathrm{e}$ & $11.241 \pm 0.464 \mathrm{c}$ & 1104 \\
\hline 3-HEXEN-1-OL-ACETATE 1005 & $12.923 \pm 0.245 \mathrm{ef}$ & nd & nd \\
\hline 3-CARENE16.669 $\pm 0.379 \mathrm{~b}$ & $12.875 \pm 0.296 f$ & $15.721 \pm 0.106 b$ & 1011 \\
\hline 1-OCTEN-3- L14.811 $\pm 0.025 \mathrm{de}$ & $11.527 \pm 0.029 \mathrm{~g}$ & nd & 980 \\
\hline 1-HEXANOL, 2-ETHYL1030 & nd & $14.996 \pm 0.704 b$ & $15.794 \pm 0.079 \mathrm{c}$ \\
\hline a-PINENE18.585 $\pm 0.000 \mathrm{a}$ & 937 & nd & $17.083 \pm 0.213 \mathrm{a}$ \\
\hline ETHANOL, 2-(2- BUTOXYETHOXY)- ACETATE nd & nd & $19.167 \pm 0.000 \mathrm{a}$ & 1366 \\
\hline HEXANAL & $14.568 \pm 0.004 \mathrm{e}$ & nd & nd 880 \\
\hline
\end{tabular}

Within the row means with the same letter are not significantly different. Means separated using Turkey HSD test.

nd: not detected, RI: retention index

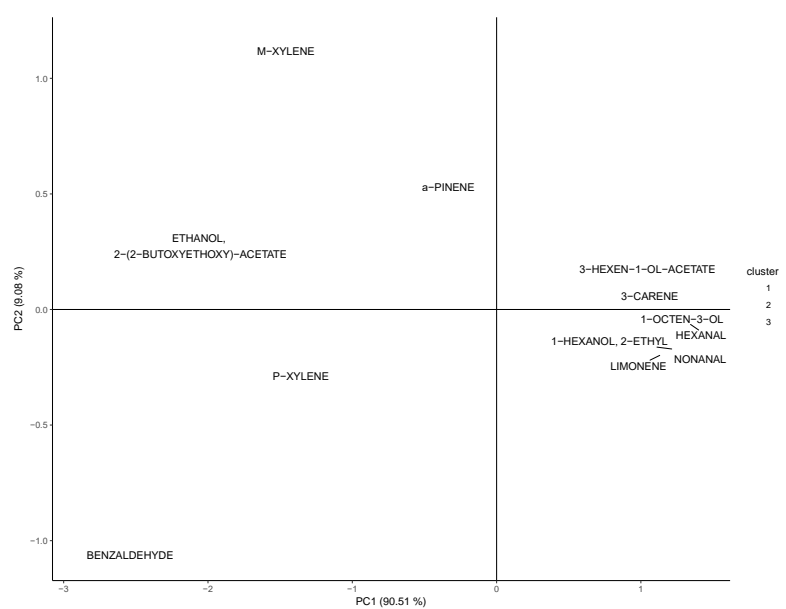

Figure 2: Biplot showing the ordination of the clustered volatile compounds

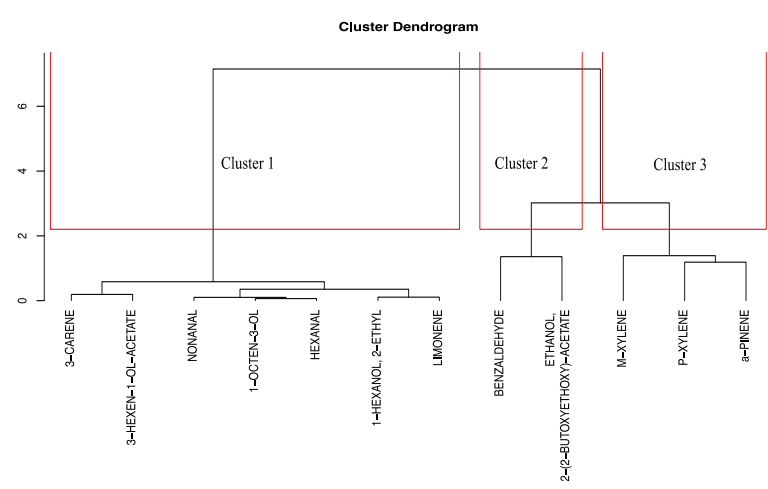

Figure 3: Dendrogram showing relationship among 12 volatile compounds from pods of black-eye cowpea based on their relative abundance

The rectangular boxes represent each cluster.

\section{Identification and Chemical Analysis of Volatile} Compounds from Pods of Borno-Brown Cultivar The analysis of the volatiles from the cowpea cultivars revealed that a total of 9 were emitted from the pods of Borno brown cultivar; all 9 compounds were detected on the developing pods, but longifolene was not present on the fully developed and mature pods (Table 3). The PCA showed that components
Table 2: PCA of the data set on 12 compounds from pods of black-eye cowpea showing the scores in the various components

\begin{tabular}{llll}
\hline Compounds & PC1 & PC2 & PC3 \\
\hline P-XYLENE & -1.2883 & -0.2529 & -0.2950 \\
M-XYLENE & -1.3935 & 1.15360 & 0.1068 \\
a-PINENE & -0.3953 & 0.4986 & -0.0659 \\
BENZALDEHYDE & -2.8638 & -1.0622 & 0.1453 \\
3-CARENE & 1.1223 & 0.0251 & 0.0693 \\
1-HEXANOL, 2-ETHYL & 1.2135 & -0.1707 & 0.0120 \\
ETHANOL, 2-(2- & & & \\
BUTOXYETHOXY)-ACETATE & -2.6734 & 0.2737 & -0.0121 \\
LIMONENE & 1.1304 & -0.1986 & 0.0749 \\
3-HEXEN-1-OL-ACETATE & 0.9822 & 0.1416 & 0.0021 \\
1-OCTEN-3-OL & 1.4002 & -0.0888 & 0.0058 \\
NONANAL & 1.4047 & -0.1804 & -0.0494 \\
HEXANAL & 1.3610 & -0.1392 & 0.0062 \\
\hline
\end{tabular}

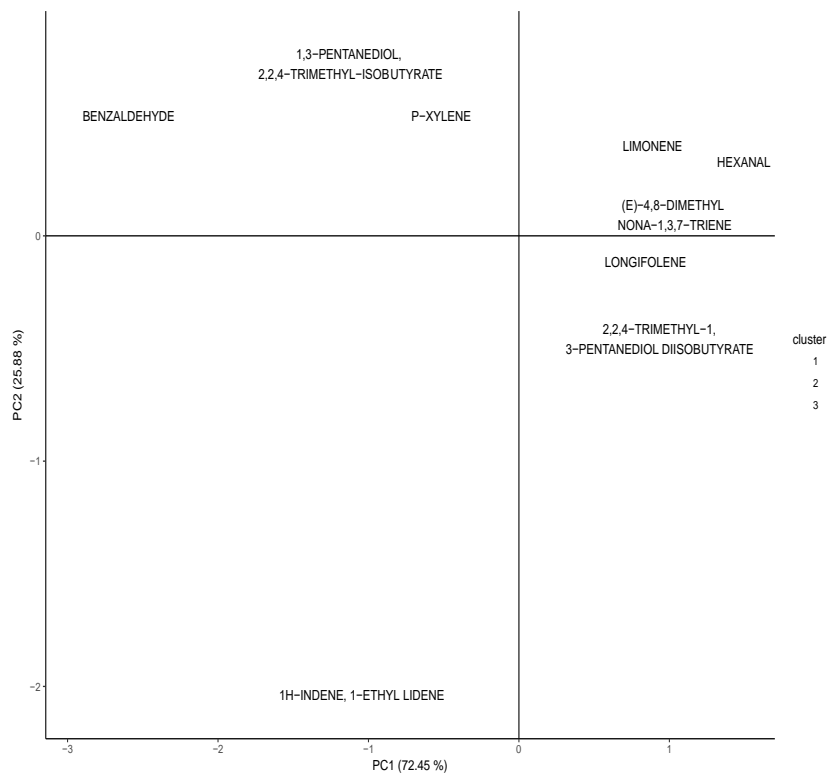

Figure 4: Biplot showing the ordination of the volatile compounds from pods of Borno-brown cultivar

1 and 2 explained over $98 \%$ of the variances in the abundance of VOCs examined on pods of black-eye cowpea (Figure 4) and all the 9 compounds showed loadings in the first two components. 
Table 3: GC-MS analysis of volatile organic compounds emitted by $2 \mu 1$ of air entrainment sample of Borno-brown pod $($ mean $\pm \mathrm{SD})$

\begin{tabular}{|c|c|c|c|}
\hline Developing pods & Fully developed pods & Mature pods & RI \\
\hline BENZALDEHYDE $\quad 16.00 \pm 0.126 \mathrm{a}$ & $17.234 \pm 0.08 \mathrm{a}$ & $17.601 \pm 0.144 \mathrm{abc}$ & 962 \\
\hline 1H-INDENE, 1-ETHYL LIDENE 15.224 $\pm 0.235 \mathrm{ab}$ & $15.583 \pm 0.579 \mathrm{c}$ & $18.218 \pm 0.261 \mathrm{a}$ & 1335 \\
\hline P-XYLENE $15.155 \pm 0.721 \mathrm{ab}$ & $16.463 \pm 0.112 b$ & $16.491 \pm 0.274 \mathrm{~cd}$ & 865 \\
\hline 1,3-PENTANEDIOL-2,2,4-TRIMETHYL-ISOBUTYRATE $14.375 \pm 1.433 \mathrm{abc}$ & $16.965 \pm 0.397 \mathrm{ab}$ & $16.772 \pm 0.049 \mathrm{bcd}$ & 1380 \\
\hline LIMONENE14.223 $\pm 0.061 \mathrm{abc}$ & $15.592 \pm 0.0134 \mathrm{c}$ & $15.744 \pm 0.095 \mathrm{~d}$ & 1030 \\
\hline LONGIFOLENE $13.094 \pm 1.723 \mathrm{bc}$ & nd & nd & 1405 \\
\hline 2,2,4- TRIMETHYL-1, 3-PENTANEDIOL DIISOBUTYRATE12.965 $\pm 0.813 \mathrm{bc}$ & $15.076 \pm 0.014 \mathrm{c}$ & $17.955 \pm 1.333 \mathrm{ab}$ & 1580 \\
\hline HEXANAL $\quad 12.416 \pm 0.457 \mathrm{c}$ & $13.706 \pm 0.0126 \mathrm{~d}$ & $13.873 \pm 0.257 \mathrm{e}$ & 880 \\
\hline (E)-4,8-DIMETHYL NONA-1,3,7-TRIENE & $12.888 \pm 0.244 \mathrm{e}$ & $15.599 \pm 0.017 \mathrm{~d}$ & 1116 \\
\hline
\end{tabular}

The cluster analysis classified the compounds in three clusters; 1h-indene, 1-ethyl lindene, representing cluster 2 has no similarity with any other compound and other compounds in the same cluster have similar abundance profile (Figure 5). The PCA biplot and dendrogram fully describe how these compounds are related. The chemical analysis of the compounds indicated that they varied significantly on pods of Borno-brown cowpea $(\mathrm{F}=$ 100.59, df $=8,26, P<0.01$; Tables 3 and 4). Benzaldehyde, was significantly more abundant, followed by $1 \mathrm{~h}$-indene, 1 -ethyl lindene and p-xylene on developing pods of Borno-brown cowpea; whereas, in the fully developed pods, benzaldehyde was significantly dominant, followed by $2,2,4$ trimethyl-isobutyrate and p-xylene (Table 3 ). On the mature pods, 1h-indene, 1-ethyl lindene was more abundant, followed by 3-pentanediol, diisobutyrate and benzaldehyde. However, (E)-4,8-dimethyl nona-1,3,7-triene was the least abundant compounds on developing and fully developed pods of Bornobrown cowpea; whereas, hexanal was the least abundant on the mature pods (Table 3).

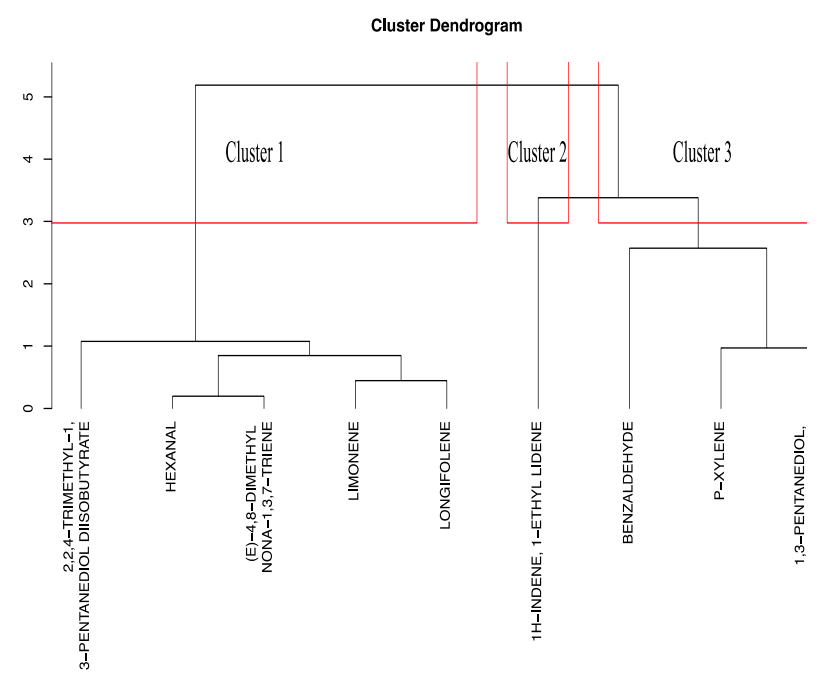

holust (", "ward.D2")

Figure 5: Dendrogram showing relationship among 9 volatile compounds from pods of Borno-brown cowpea based on their relative abundance

The rectangular boxes represent each cluster.

\section{DISCUSSION}

Our study identified 12 volatile compounds on the pods of black-eyed cowpea and 9 on the pods of Borno-brown cultivar. The compounds varied in abundance and numbers across the three developmental stages examined and majority of those identified in this work have been reported in other studies (Mushobozy, et al., 1993; Adhikary et al., 2015; Zhou et al., 2015) to trigger behavioural responses on insects. Benzaldehyde was present and abundant at all the developmental stages of both cowpea cultivars, thus suggesting it could be playing an important role in host location by the pest. Its role in mediating host-choice on Acanthoscelides obtectus (Khelfane-Goucem et al., 2014), Vicia faba (Webster et al., 2008) and Maruca vitrata (Zhou et $a l ., 2015)$ have been suggested.

The headspace volatile samples of the cowpea pods collected at different developmental stages elicited varying behavioural (olfactometer) attraction on mated females of $C$. maculatus. The results show that the beetles moved towards odour samples from the fully developed pods (of blackeyed cultivar) and mature pods (of black-eyed and Borno-brown cultivars), respectively. This suggests that the beetles' attraction to the host plant increases with the pod's age. The preference is likely driven by the fact that the host beans (the primary target) are developing as the pods mature. In the other hand, the beetle's preference for older pods could be due to the organic compounds associated with the developing seeds in the pods which may be difficult to detect at an early podding stage. Earlier work (Zannou et al., 2003) revealed that cowpea plants with pods attracted more beetles compared to cowpea plants without pods. The findings in the present study also agree with Ouedraogo and Huignard, (1981) that dry and mature pods of cowpea are vulnerable to $C$. maculatus infestations. Similarly, Abagale et al. (2019) found that the banana weevil (Cosmopolites sordidus) was attracted to the odour of senesced banana leaf material. The variation in attraction to the pods are linked with the differences in the chemical composition of the plant part which affects the abundance and quality of VOCs (Li et al., 2016; Shiojiri and Karban, 2006). 
Table 4: PCA of the dataset on 9 compounds from pods of Borno-brown cowpea showing the scores in the various components

\begin{tabular}{llll}
\hline Compounds & PC1 & PC2 & PC3 \\
\hline BENZALDEHYDE & -2.9247424 & 0.53395161 & 0.14308114 \\
HEXANAL & 1.4804515 & 0.28392084 & 0.10658366 \\
P-XYLENE & -0.4480953 & 0.57735731 & 0.29599372 \\
LIMONENE & 0.8250549 & 0.35727251 & 0.08089173 \\
1H-INDENE, 1-ETHYL LIDENE & -1.1065272 & -2.08567898 & 0.02205382 \\
2,2,4-TRIMETHYL-1,3-PENTANEDIOL DIISOBUTYRATE & 0.8039782 & -0.54510722 & -0.2314637 \\
1,3-PENTANEDIOL, 2,2,4-TRIMETHYL- ISOBUTYRATE & -0.9859765 & 0.85121692 & -0.4637878 \\
(E)-4,8-DIMETHYL NONA-1,3,7-TRIENE & 1.4445936 & 0.09429446 & 0.06990006 \\
LONGIFOLENE & 0.9112631 & -0.06722745 & -0.0232527 \\
\hline
\end{tabular}

The results of the GC-MS analyses of the headspace volatile samples from the pods showed that the VOCs profile differed with cowpea cultivar and pod's age. The variation in gene sequence has been suggested to be affecting the chemical composition of plant cultivars or ecotypes, thus, triggering the release of diverse blends of compounds (Köllner et al., 2004). It has been shown that as a plant grows, the ratio of compounds present changes (Najar-Rodriguez et al., 2010; Vallat and Dorn, 2005). Most of the compounds identified (Benzaldehyde, M-xylene, Hexanal, P-xylene, Limonene etc.), are among the common volatile compounds associated with most leguminous plant parts (Blight et al., 1984; Webster et al., 2008). Although they have been only identified as candidate compounds in this study, a probable role in eliciting behavioural attraction in the beetle still remains a strong possibility.

\section{CONCLUSION}

In summary, this study has (a) demonstrated that mated females of $C$. maculatus are attracted to fully developed and mature pods of cowpea, (b) identified the volatile compounds that could be inducing the beetles' behavioural attraction to older cowpea pods (c) shown that volatile compounds composition and abundance profile vary between cowpea cultivars at different pods' developmental stage. This is a step forward in confirming that volatile compounds in growing plants can drive host identification and selection by $C$. maculatus. The approach presents great potential for the management of the pest using semiochemical-based approach.

\section{REFERENCES}

Abagale S.A., Woodcock C.M., Chamberlain K. et al. (2019). Attractiveness of host banana leaf materials to the banana weevil, Cosmopolites sordidus in Ghana for development of field management strategies. Pest Management Science, 75 (2), 549-555

Adhikary P., Mukherjee A. and Barik A. (2015). Attraction of Callosobruchus maculatus (F.) (Coleoptera: Bruchidae) to four varieties of Lathyrus sativus L. seed volatiles. Bulletin of Entomological Research, 105 (2), 187-201
Agelopoulos N., Birkett M.A., Hick A.J. et al. (1999). Exploiting semiochemicals in insect control. Pesticide Science, 55 (3), 225-235

Bendera M., Ekesi S., Ndung'u M., Srinivasan R. and Torto B. (2015). A major host plant volatile, 1-octen3 -ol, contributes to mating in the legume pod borer, Maruca vitrata (Fabricius) (Lepidoptera: Crambidae). The Science of Nature, 102 (9), 47

Blight M.M., Pickett J.A., Smith M.C. and Wadhams L.J. (1984). An aggregation pheromone of Sitona lineatus. Natural sciences, 71 (9), 480

Boué S.M., Shih B.Y., Carter-Wientjes C.H. and Cleveland T.E. (2003). Identification of volatile compounds in soybean at various developmental stages using solid phase microextraction. Journal of Agricultural and Food Chemistry, 51 (17), 4873-4876

Bruce T.J.A., Wadhams L.J., and Woodcock C.M. (2005). Insect host location: A volatile situation. Trends in Plant Science, 10 (6), 269-274

Caswell G.H. (1984). The value of the pod in protecting cowpea seed from attack by bruchid beetles. Samaru Journal of Agricultural Research (Nigeria), 2, 29-55

Ceballos R., Fernández N., Zúñiga S. and Zapata N. (2015). Electrophysiological and behavioral responses of pea weevil Bruchus pisorum L. (Coleóptera: Bruchidae) to volatiles collected from its host Pisum sativum L. Chilean Journal of Agricultural Research, 75 (2), 202-209

Djossou J. (2006). Study of the Possibilities of using Formulations based on Dried Fruits of Xylopia aethiopica Dunal (Annonaceae) for the Protection of Cowpea Stocks against Callosobruchus maculatus Fabricius (Coleoptera: Bruchidae). MSc Dissertation. Faculty of Agronomic Sciences of Gembloux, Belgium

Dudareva N., Pichersky E. and Gershenzon J. (2004). Biochemistry of plant volatiles. Plant Physiology, 135 (4), 1893-1902

Hammer K.A., Carson C.F. and Riley T.V. (2003). Antifungal activity of the components of Melaleuca alternifolia (tea tree) oil. Journal of Applied Microbiology, 95 (4), 853-860

Ignacimuthu S., Wäckers F.L. and Dorn S. (2000). The role of chemical cues in host finding and acceptance by Callosobruchus chinensis. Entomologia Experimentalis et Applicata, 96 (3), 213-219

Kébé K. and Sembène M. (2011). Cowpea field infestation by bruchids: Biological and ecological data. Journal of Applied Biosciences, 41, 2788-2796

Khelfane-Goucem K., Medjdoub-Bensaad F., Leppik E. and Frérot B. (2014). Dry bean volatile organic compounds mediating host choice in Acanthoscelides obtectus Say (Coleoptera: Chrysomelidae: Bruchinae). Annales de La Société Entomologique de France (N.S.), 50 (2), 167-176 
Köllner T.G., Schnee C., Gershenzon J. and Degenhardt J. (2004). The variability of sesquiterpenes emitted from two cultivars is controlled by allelic variation of two terpene synthase genes encoding stereoselective multiple product enzymes. The Plant Cell, 16 (5), 1115-1131

Li Y., Ma H., Wan Y. et al. (2016). Volatile organic compounds emissions from luculia pinceana flower and its changes at different stages of flower development. Molecules, 21 (4), 531

Messina F.J. (1984). Influence of cowpea pod maturity on the oviposition choices and larval survival of a bruchid beetle Callosobruchus maculatus. Entomologia Experimentalis et Applicata, 35 (3), 241-248

Mushobozy D.K., Pierce H.D. and Borden J.H. (1993). Evaluation of 1-octen-3-ol and nonanal as adjuvants for aggregation pheromones for three species of cucujid beetles (Coleoptera: Cucujidae). Journal of Economic Entomology, 86 (6), 1835-1845

Najar-Rodriguez A.J., Galizia C.G., Stierle J. and Dorn S. (2010). Behavioral and neurophysiological responses of an insect to changing ratios of constituents in host plant-derived volatile mixtures. The Journal of Experimental Biology, 213 (19), 3388-3397

Ouedraogo A.P. and Huignard J. (1981). Polymorphism and ecological reactions in Callosobruchus Maculatus F. (Coleoptera, Bruchidae) in upper volta. In: V. Labeyrie (Ed.), The Ecology of Bruchids Attacking Legumes (Pulses) (pp. 175-184). Springer, Dordrecht

Pare P.W. and Tumlinson J.H. (1999). Update on plantinsect interactions plant volatiles as a defense against insect herbivores. Plant Physiology, 121 (2), 325-331

Reinhard J., Srinivasan M.V. and Zhang S. (2004). Olfaction: scent-triggered navigation in honeybees. Nature, 427 (6973), 411-411

Sharkey T.D. and Yeh S. (2001). Isoprene emission from plants. Annual Review of Plant Biology, 52 (1), 407-436

Sharkey T.D., Wiberley A.E. and Donohue A.R. (2008). Isoprene emission from plants: Why and how. Annals of Botany, 101 (1), 5-18

Shiojiri K. and Karban R. (2006). Plant age, communication, and resistance to herbivores: young sagebrush plants are better emitters and receivers. Oecologia, 149 (2), 214-220

Takabayashi J. and Dicke M. (1996). Plant-carnivore mutualism through herbivore-induced carnivore attractants. Trends in Plant Science, 1 (4), 109-113
Takabayashi J., Dicke M. and Posthumus M.A. (1994). Volatile herbivore-induced terpenoids in plant-mite interactions: Variation caused by biotic and abiotic factors. Journal of Chemical Ecology, 20 (6), 1329-1354

Taylor T.A. and Agbaje L.A. (1974). Flight activity in normal and active forms of Callosobruchus maculatus (F.) in a store in Nigeria. Journal of Stored Products Research, 10 (1), 9-16

Uechi K., Matsuyama S. and Suzuki T. (2007). Oviposition attractants for Plodia interpunctella (Hübner) (Lepidoptera: Pyralidae) in the volatiles of whole wheat flour. Journal of Stored Products Research, 43 (2), 193-201

Ugwu J.A., Omoloye A.A. and Ogunfumilayo A.O. (2018). Evaluation of traps and attractants for mass trapping of African invader fly, Bactrocera invadens on mango in South West Nigeria. Agro-Science, 17 (3), 40-45. DOI: https://dx.doi.org/10.4314/as.v17i3.7

Umar A. and Turaki J.M. (2014). Comparative studies on the biology of Callosobruchus maculatus (F.) on soybeans and bambara groundnut. Journal of Entomology and Zoology Studies, 2 (4), 58-61

Vallat A. and Dorn S. (2005). Changes in volatile emissions from apple trees and associated response of adult female codling moths over the fruit-growing season. Journal of Agricultural and Food Chemistry, 53 (10), 4083-4090

Van Wassenhove F.A., Dirinck P.J., Schamp N.M. and Vulsteke G.A. (1990). Effect of nitrogen fertilizers on celery volatiles. Journal of Agricultural and Food Chemistry, 38 (1), 220-226

Ward J.H. (1963). Hierarchical grouping to optimize an objective function. Journal of the American Statistical Association, 58, 236-244

Webster B., Bruce T., Dufour S. et al. (2008). Identification of volatile compounds used in host location by the black bean aphid, Aphis fabae. Journal of Chemical Ecology, 34 (9), 1153-1161

Zannou E.T., Glitho I.A., Huignard J. and Monge J.P. (2003). Life history of flight morph females of Callosobruchus maculatus F.: evidence of a reproductive diapause. Journal of Insect Physiology, 49 (6), 575-582

Zhou J., Zhang N., Wang P. et al. (2015). Identification of host-plant volatiles and characterization of two novel general odorant-binding proteins from the legume pod borer, Maruca vitrata Fabricius (Lepidoptera: Crambidae). Plos One, 10 (10), p. e0141208 